\title{
The molecular basis of ornithine transcarbamylase deficiency: modelling the human enzyme and the effects of mutations
}

\author{
Mendel Tuchman, Hiroki Morizono, Orit Reish, Xiaoling Yuan, Norma M Allewell
}

\begin{abstract}
Human ornithine transcarbamylase is a trimer with $46 \%$ amino acid sequence homology to the catalytic subunit of $E$ coli aspartate transcarbamylase. Secondary structure predictions, distributions of hydrophilic and hydrophobic regions, and the pattern of conserved residues suggest that the three dimensional structures of the two proteins are likely to be similar. A three dimensional model of ornithine transcarbamylase was generated from the crystal structure of the catalytic subunit of $E$ coli aspartate transcarbamylase in the holoenzyme, by aligning the sequences, building in gaps, and minimising the energy. The binding sites for carbamyl phosphate in both enzymes are similar and the ornithine binding site in ornithine transcarbamylase appears to be in the same location as the L-aspartate binding site in aspartate transcarbamylase, with negatively charged side chains replaced by positively charged residues. Mutations in the ornithine transcarbamylase gene found in patients with hyperammonaemia of the "neonatal type" are clustered in important structural or functional domains, either in the interior of the protein, at the active site, or at the interchain interface, while mutations found in patients with milder "late onset" disease are located primarily on the surface of the protein. The predicted effects of all known missense mutations and in frame deletions in the ornithine transcarbamylase gene on the structure and function of the mature enzyme are described.
\end{abstract}

( $\mathcal{F}$ Med Genet 1995;32:680-688)

Ornithine transcarbamylase deficiency (OTCD), an $\mathrm{X}$ linked disorder, is the most common inherited defect of the urea cycle. ${ }^{1}$ The human ornithine transcarbamylase (OTC) gene has been localised to the short arm of the $\mathrm{X}$ chromosome, band $\mathrm{p} 21.1,{ }^{2}$ and it has been cloned and sequenced by Horwich $e t a l^{\beta}$ and Hata et $a l .{ }^{4}$ Mature mitochondrial human OTCase (ornithine transcarbamylase enzyme) was first purified in $1978^{5}$ and shown to be a trimer with 322 amino acids and a molecular weight of approximately 36000 Daltons per polypeptide chain.

Approximately 70 mutations and polymorphisms in the human OTC gene have been described $^{67}$ and a number of biochemical studies of unpurified mutant human OTCases have been reported. ${ }^{8}$ However, for better understanding of the deleterious effects of mutations in the OTC gene, a structural model of the enzyme is essential. The mutations identified so far indicate that most patients with OTCD have "private" alterations rarely seen in other families. Even the few recurring mutations in $\mathrm{CpG}$ dinucleotides such as R141Q, which causes neonatal disease, and R277W, which causes late onset disease, are seen in a small fraction of patients, probably less than $10 \% .^{6}$ In a large proportion of OTCase deficient families, identification of the underlying mutation may be the only tool for providing accurate carrier testing and prenatal diagnosis. Thus, a method for predicting that a mutation found in a patient is deleterious rather than an innocent polymorphism is necessary.

Although very little is known about structure/ function relationships in human OTCase, bacterial and yeast OTCases have been studied in greater detail. The yeast and $E$ coli enzymes have many features in common with the catalytic subunit of $E$ coli aspartate transcarbamylase enzyme (ATCase). ATCase catalyses the first committed step in pyrimidine synthesis in which the carbamyl group of carbamyl phosphate is transferred to the $\alpha$ amino group of Laspartate. ATCase is an extensively studied allosteric enzyme containing six catalytic and six regulatory polypeptide chains. The six catalytic chains are organised in two identical subunits, each containing three chains. ${ }^{9}$ Isolated catalytic subunits possess full enzymatic activity. Each catalytic polypeptide chain consists of an N-terminal polar domain, which binds carbamyl phosphate, and a C-terminal equatorial domain, which binds L-aspartate. ${ }^{10}$

As seen in $E$ coli ATCase, binding of substrates and products to $E$ coli OTCase is ordered, with carbamyl phosphate binding first and phosphate being released last. ${ }^{11} E$ coli ATCase binds L-aspartate cooperatively and 
binding of $\mathrm{Zn}$ (II) induces cooperativity also in $E$ coli OTCase by interacting with a Cys residue at the ornithine binding site and inducing a conformational change. ${ }^{12-14}$ Binding of carbamyl phosphate in $E$ coli OTCase induces a conformational change ${ }^{15}$ as it does in $E$ coli ATCase; however, in contrast to ATCase, addition of ornithine produces no detectable additional change in conformation.

An elegant demonstration of the structural similarity between $E$ coli ATCase and OTCase was provided by Houghton et $a l^{16}$ who fused the polar domain of $E$ coli OTCase with the equatorial domain of $E$ coli ATCase. The resulting chimeric protein assembled into a trimer, bound carbamyl phosphate and Laspartate, and catalysed the formation of carbamyl aspartate. This observation suggests that the structural features required for creating the proper tertiary and quaternary structure for binding carbamyl phosphate and transferring its carbamyl group to the $\alpha$ amino group of Laspartate or the terminal $\delta$ amino group of L-ornithine are essentially identical in both enzymes.

Since human and $E$ coli OTCase have $58.8 \%$ sequence similarity, the three dimensional structures of the two are almost certainly similar. Although $E$ coli OTCase has been crystallised, ${ }^{17}$ its structure prediction did not extend beyond determining the space group. However, the sequence, structural, and functional similarities between human OTCase and the catalytic subunit of $E$ coli ATCase suggest that it is possible to develop a structural model of OTCase based upon the crystal structure of $E$ coli ATCase. ${ }^{18-20}$ We describe here a structural model of human OTCase and the results of mapping onto the model mutations found in the OTCase genes of patients with OTCD. Our results indicate that this model is useful for predicting the functional effects of various mutations on mutant OTCases.

\section{Methods}

A computerised search of crystallised proteins for regions of sequence similarity was performed using the Basic Local Alignment Search Tool (BLAST) server based at the National Center for Biotechnology Information. ${ }^{21}$ The search showed that of all crystallised proteins, $E$ coli ATCase has the highest degree of homology to human OTCase. The human OTCase amino acid sequence was aligned with that of the ATCase catalytic chain using the Needleman-Wunsch algorithm from the gap module of the Genetics Computer Group (GCG) suite. ${ }^{223}$ Most of the gaps were located outside $\alpha$ helices or $\beta$ strands of the ATCase structure. Frodo, a general purpose molecular modelling and display program, was used to generate a preliminary model by replacing residues in aligned regions of the sequence of the ATCase crystal structure (1RAI in the Brookhaven Protein Data Bank) with amino acid residues of human OTCase. ${ }^{2425}$ Three insertions of four to five residues each were built in with conformations of similar sequences in the Brookhaven Protein Data Bank, identified through a
BLAST search. Two single amino acids were also inserted. Steep descent energy minimisation was performed by the method of Powell $^{26}$ with the program X-PLOR ${ }^{27}$ to improve the orientation of side chains and bond geometry and the movement of the backbone was constrained with a high energy term $(20 \mathrm{kcal})$ to prevent the structure from collapsing.

ATCase and OTCase sequences from other organisms were identified by querying the Predict Protein server at the European Molecular Biology Laboratory in Heidelberg with the $E$ coli ATCase and human OTCase sequences. ${ }^{28-30}$ The alignments of these sequences with those of human OTCase and $E$ coli ATCase were used to identify evolutionary invariant residues likely to be important for proper folding, assembly, and catalytic activity.

Of a total of 62 mutations found in patients with OTCD, ${ }^{67} 40$ mutations affecting the code of mature OTCase (38 missense mutations and two in frame deletions of three nucleotides each) do not result in large deletions, insertions, or incomplete polypeptide chains. Eighteen mutations were found in patients with neonatal onset of disease, 14 in late onset disease, and eight were found in females heterozygous for OTCD. All these mutations were mapped onto the structural model of OTCase and their effects on the structure/function of the enzyme were predicted based upon the location in the OTCase model and the chemical alteration created by the respective mutation.

\section{Results and discussion}

PRIMARY AND SECONDARY PROTEIN SEQUENCE COMPARISONS OF ALIGNMENT

Both insertions and deletions were needed to align $E$ coli ATCase with human OTCase. Five insertions were needed in the ATCase sequence, two involving single residues and three involving four or five residues. Using different values for the gap and length weights did not change the positions of these insertions significantly. Two of the larger insertions occurred at the ends of secondary structure in ATCase (residues 235-238 and 261-264), while the third lies in a loop between an $\alpha$ helix and a $\beta$ strand (residues 71-75). There were also four single residue deletions and three deletions of two residues each in the ATCase sequence. This alignment yielded a percent similarity of $46.36 \%$ and a percent identity of $26 \cdot 82 \%$.

\section{TERTIARY AND QUATERNARY DESCRIPTION AND} COMPARISONS

The positions of protein backbone atoms were constrained in the energy minimisation by a high energy term producing an overall folding of the OTCase model which is very similar to that of the catalytic chain of ATCase (fig 1). The N-terminal half of the protein forms the polar domain, while the C-terminal half forms the equatorial domain. Each domain has a core composed of a parallel $\beta$ sheet enclosed by $\alpha$ helices. The topology of this repeating $\alpha-\beta-\alpha$ motif is similar to a "Rossman fold", a folding 

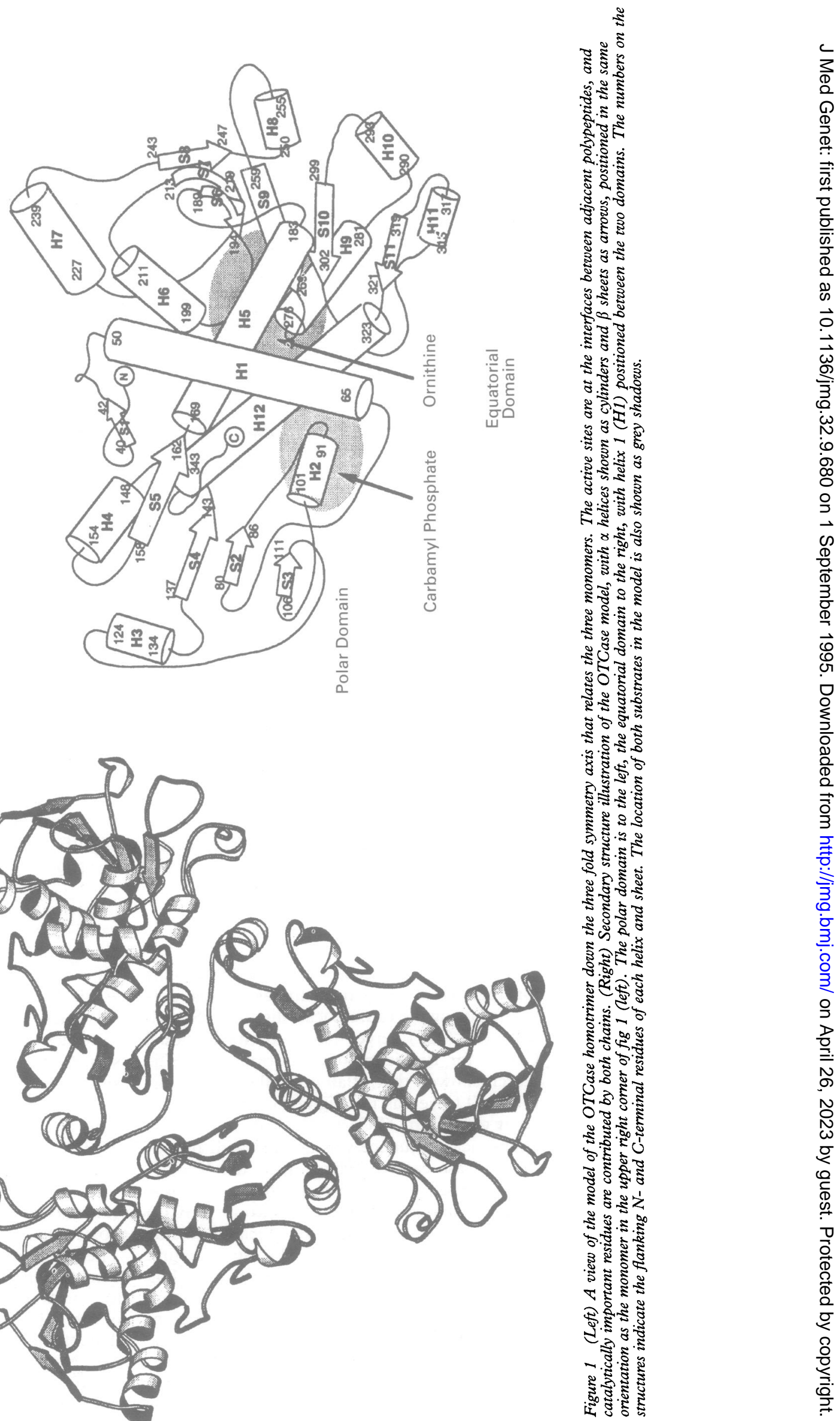


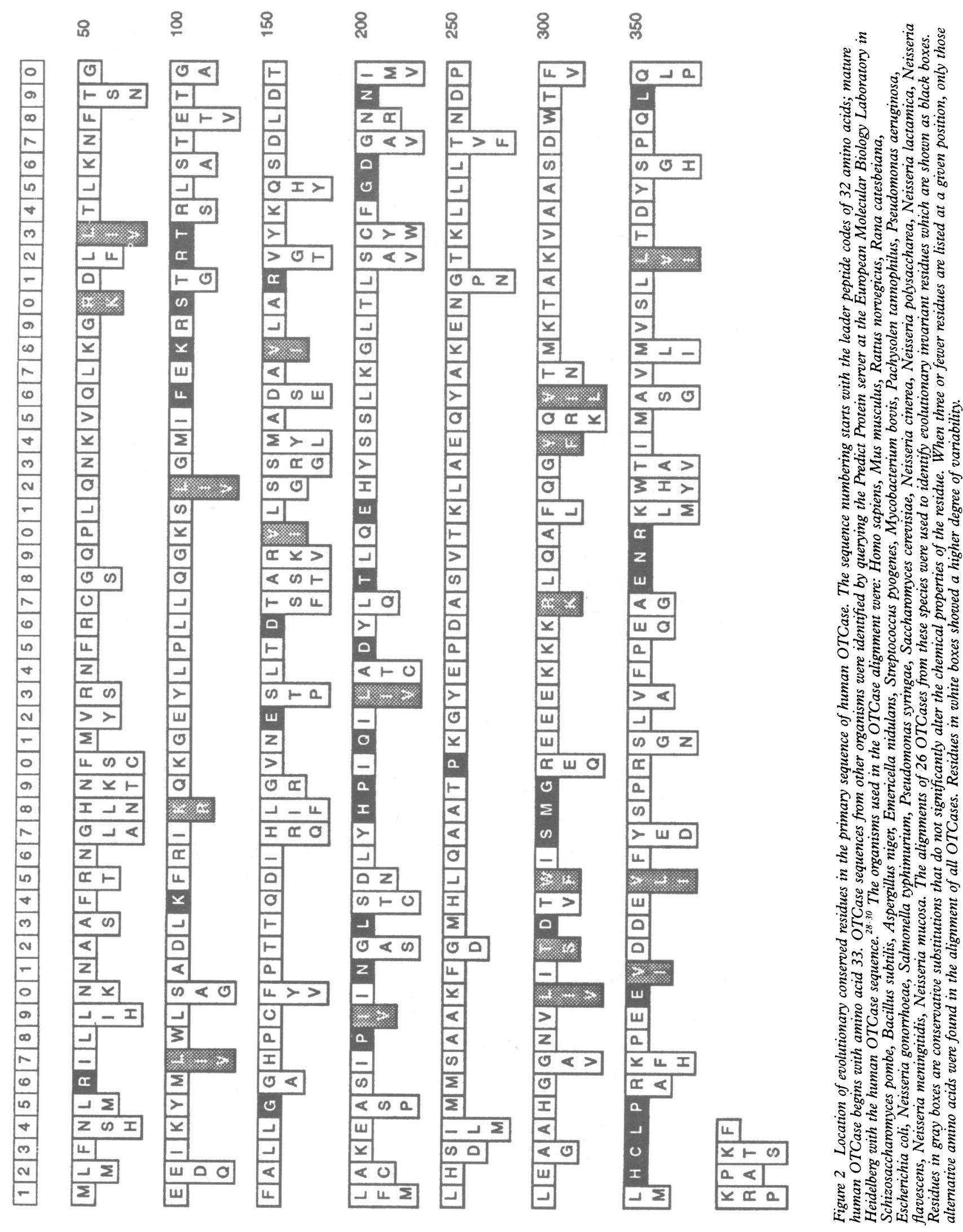



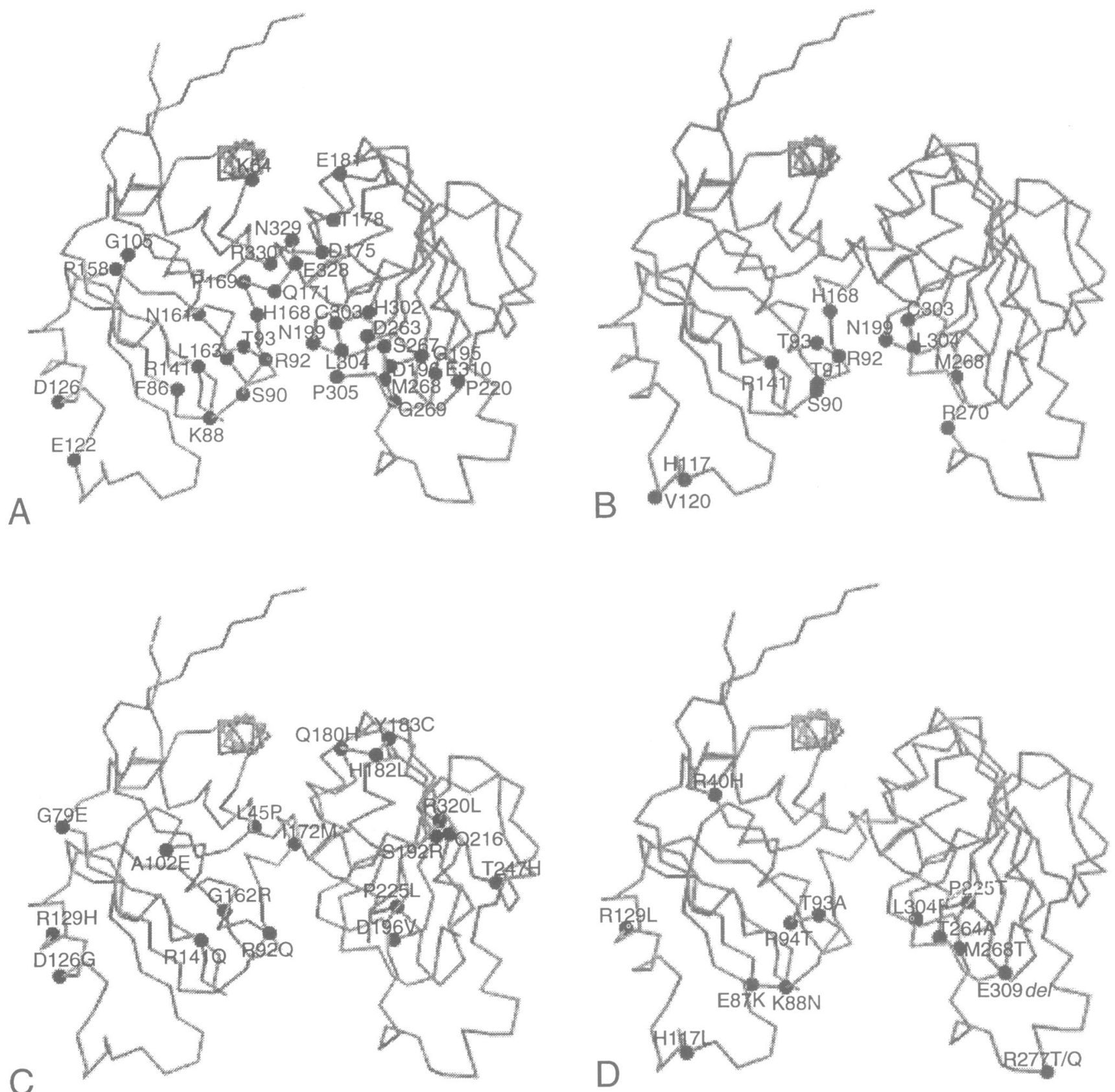

Figure 3 Positions of conserved residues, residues participating in the active site, and the location of mutations in the structural model of human Figure 3 Positions of conserved residues, residues partar to that shown in fig 1. The polar domain is to the left, the equatorial domain to the right. OTCase. The orientation is approximately perpendicular to that shown in fig 1 . The polar domain is to the left, the equatorial domain to the right. of residues that were $100 \%$ conserved in the alignment of 26 OTCases from different species. Residues in the core of the protein are required for folding

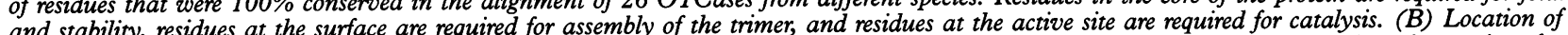
active site residues. The two residues at the far left $(H 117, V 120)$ belong to the active site of the adjacent monomer. (C) Location of mutations found in patients with neonatal disease. Note the clustering of mutations around the active site, and in the core of the protein. (D) Location of mutations found in patients with late onset disease. Most of these mutations are located near the active site, but on the surface of the protein.

pattern found in several phosphate binding proteins. ${ }^{31}$ Two helices link the two domains, one formed by residues near the middle of the primary sequence (H5) and a second comprised of residues near the C-terminus (H12) which runs back to the polar domain (fig 1, right). The $\mathrm{H} 5$ helix appears to maintain the separation of the domains and to contribute residues that stabilise the interface between polypeptide chains in the trimer. As shown in fig 1 (left), in the assembled trimer, the tip of the polar domain of one chain interacts with the interdomain region of a neighbouring chain to form the active site.
ACTIVE SITE ALIGNMENT AND COMPARISONS BETWEEN OTCASE AND ATCASE

The carbamyl phosphate binding motif is highly conserved in the OTCase and ATCase structures. All six residues that interact with carbamyl phosphate in ATCase are conserved in OTCase (Ser 90, Thr 91, Arg 92, Thr 93, Arg 141, and His 168; OTCase sequence) and have the same relative positions in the model. However, Lys 88 in OTCase located near the carbamyl phosphate binding site is replaced by Glu in ATCase.

Since ornithine reacts with carbamyl phosphate via its $\delta$ amino group, while the reactive 
Mutations in the human ormithine transcarbamylase gene, their predicted effects, and clinical phenotypes

\begin{tabular}{|c|c|c|c|c|c|c|c|}
\hline Exon & Codon* & Mutation & $\begin{array}{l}\text { Amino acid } \\
\text { change }\end{array}$ & Location $†$ & $\begin{array}{l}2^{\circ} \text { structure } \\
\text { interactions }\end{array}$ & Postulated structure/function effect $\ddagger$ & Clinical/biochemical phenotype $₫$ \\
\hline 2 & 40 & $\mathrm{CGT} \rightarrow \mathrm{CAT}$ & $\mathrm{Arg} \rightarrow \mathrm{His}$ & Polar S1 & $\mathrm{H} 1, \mathrm{H} 12$ & & Late onset, $<1 \mathrm{y}$ of age \\
\hline 2 & 45 & $\mathrm{CTA} \rightarrow \mathrm{CCA}$ & Leu $\rightarrow$ Pro & Polar & & $\begin{array}{l}\text { Lose interactions maintaining proper } \\
\text { orientation of the polar and equatorial } \\
\text { domains }\end{array}$ & Neonatal disease \\
\hline 2 & 60 & $\mathrm{TCA} \rightarrow \mathrm{TTA}$ & Ser $\rightarrow$ Leu & Polar H1 & $\mathrm{H} 5, \mathrm{H} 12$ & $\begin{array}{l}\text { Stabilises orientation of the two interdomain } \\
\text { helices }\end{array}$ & Female, 2 y \\
\hline 3 & 79 & $\mathrm{GGG} \rightarrow \mathrm{GAG}$ & Gly $\rightarrow$ Glu & Polar & & Affects assembly & $\begin{array}{l}\text { Neonatal disease, } 5 \mathrm{~d} \text {, peak } \\
\mathrm{NH} 3=1300 \text {, OTCase activity }=0\end{array}$ \\
\hline 3 & $81-82$ & $\Delta \mathrm{CTT}$ & $\begin{array}{l}\text { Deletion of } \\
\text { Leu }\end{array}$ & Polar S2 & $\mathrm{S} 4, \mathrm{H} 12$ & & Female, 7 y, peak NH3 $=248$ \\
\hline 3 & 87 & $\mathrm{GAG} \rightarrow \mathrm{AAG}$ & Glu $\rightarrow$ Lys & Polar S2 & & $\begin{array}{l}\text { Part of consensus motif for CP binding } \\
\text { Breaks ionic bond stabilising core of polar } \\
\text { domain }\end{array}$ & $\begin{array}{l}\text { Late onset, } 7 \cdot 5 \mathrm{mth} \text {, peak NH3 } \\
>700 \\
\text { OTCase activity }=0\end{array}$ \\
\hline 3 & $88 \|$ & $\mathrm{AAA} \rightarrow \mathrm{AAT}$ & Lys $\rightarrow$ Asn & Polar & S4 & $\begin{array}{l}\text { Part of consensus motif for CP binding } \\
\mathrm{K} \text { at this position used to identify OTCase } \\
\text { from ATCase }\end{array}$ & $\begin{array}{l}\text { Late onset, } 9 \text { mth, peak NH3= } \\
200 \\
\text { OTCase activity }=3 \%\end{array}$ \\
\hline 3 & $92 \|$ & $\mathrm{CGA} \rightarrow \mathrm{CAA}$ & Arg $\rightarrow \mathrm{Gln}$ & Polar H2 & & $\begin{array}{l}\text { Active site residue } \\
\text { Affects CP binding }\end{array}$ & Neonatal disease \\
\hline 3 & $93 \|$ & $\mathrm{ACA} \rightarrow \mathrm{GCA}$ & $\mathrm{Thr} \rightarrow$ Ala & Polar H2 & $\mathrm{H} 12, \mathrm{~S} 4, \mathrm{~S} 2$ & $\begin{array}{l}\text { Active site residue } \\
\text { Affects CP binding }\end{array}$ & $\begin{array}{l}\text { Late onset, } 5 \mathrm{mth} \text {, peak NH3 = } \\
379\end{array}$ \\
\hline 3 & 94 & $\mathrm{AGA} \rightarrow \mathrm{ACA}$ & $\operatorname{Arg} \rightarrow \mathrm{Thr}$ & Polar H2 & $\mathrm{H} 2$ & $\begin{array}{l}\text { Active site residue } \\
\text { Affects CP binding }\end{array}$ & $\begin{array}{l}\text { Late onset, } 7 \mathrm{y} \text {, peak } \mathrm{NH} 3=780 \\
\text { OTCase activity }=1 \% \text {, no change } \\
\text { up to } 100 \mathrm{mmol} / \mathrm{CP}\end{array}$ \\
\hline 4 & 102 & $\mathrm{GCA} \rightarrow \mathrm{GAA}$ & $\mathrm{Ala} \rightarrow \mathrm{Glu}$ & Polar & $\mathrm{S} 2, \mathrm{~S} 3$ & Affects assembly & $\begin{array}{l}\text { Neonatal disease, }<72 \mathrm{~h} \text {, peak } \\
\text { NH } 3=277 \\
\text { OTCase activity }=0\end{array}$ \\
\hline 4 & 117 & $\mathrm{CAT} \rightarrow$ CTT & His $\rightarrow$ Leu & Polar & & & $\begin{array}{l}\text { Late onset, same residue affected } \\
\text { in the spf mouse }(\mathrm{H} 117 \mathrm{~N})\end{array}$ \\
\hline 4 & $126 \|$ & $\mathrm{GAC} \rightarrow \mathrm{GGC}$ & Asp $\rightarrow$ Gly & Polar H3 & & Affects assembly & $\begin{array}{l}\text { Neonatal disease, }<72 \mathrm{~h} \text {, } \\
\text { OTCase activity }=0.9 \%\end{array}$ \\
\hline 4 & 129 & $\mathrm{CGT} \rightarrow \mathrm{CTT}$ & $\begin{array}{l}\text { Arg } \rightarrow \text { Leu }+ \\
\text { donor splice } \\
\text { error? }\end{array}$ & Polar H3 & & $\begin{array}{l}\text { Possibly inefficient translation of correct } \\
\text { message owing to splice error }\end{array}$ & Late onset \\
\hline 4 & 129 & $\mathrm{CGT} \rightarrow \mathrm{CAT}$ & $\begin{array}{l}\text { Arg } \rightarrow \text { His }+ \\
\text { donor splice } \\
\text { error? }\end{array}$ & Polar H3 & & $\begin{array}{l}\text { Possibly inefficient translation of correct } \\
\text { message owing to splice error }\end{array}$ & $\begin{array}{l}\text { Late onset, } 9 \mathrm{mth} \text {, OTCase } \\
\text { activity }=2 \cdot 1 \% \\
\text { Identical mutation to the spfASH } \\
\text { mouse }\end{array}$ \\
\hline 5 & $141 \|$ & $\mathrm{CGA} \rightarrow \mathrm{CAA}$ & $\mathrm{Arg} \rightarrow \mathrm{Gln}$ & Polar S4 & $\mathrm{S} 1, \mathrm{H} 4$ & $\begin{array}{l}141 \text { in direct contact with active site } \\
\text { residues } 86-93 \& 168 \text {. Changes in local } \\
\text { geometry as well as charge cause loss of } \\
\text { activity }\end{array}$ & $\begin{array}{l}\text { Neonatal onset, }<72 \mathrm{~h} \text {, peak } \\
\text { NH3 } 2000 \\
\text { OTCase activity }=0\end{array}$ \\
\hline $\begin{array}{l}5 \\
5\end{array}$ & $\begin{array}{l}161 \| \\
162\end{array}$ & $\begin{array}{l}\mathrm{AAT} \rightarrow \mathrm{AGT} \\
\mathrm{GGG} \rightarrow \mathrm{AGG}\end{array}$ & $\begin{array}{l}\text { Asn } \rightarrow \text { Ser } \\
\text { Gly } \rightarrow \text { Arg }\end{array}$ & $\begin{array}{l}\text { Polar S5 } \\
\text { Polar S5 }\end{array}$ & $\begin{array}{l}\mathrm{S} 1, \mathrm{H} 4, \mathrm{H} 5 \\
\mathrm{H} 4\end{array}$ & Arg makes steric intrusion into active site & $\begin{array}{l}\text { Female, } 2 \text { y, peak } \mathrm{NH} 3 \sim 400 \\
\text { Neonatal disease }<<2 \mathrm{~h} \text {, peak } \\
\mathrm{NH} 3>700 \text {, OTCase activity }=0\end{array}$ \\
\hline 5 & 172 & $\mathrm{ATC} \rightarrow \mathrm{ATG}$ & Ile $\rightarrow$ Met & $\begin{array}{l}\text { Interdomain } \\
\text { H5 }\end{array}$ & H6 & $\begin{array}{l}\text { Weakens orientation of interdomain } \\
\text { interface }\end{array}$ & $\begin{array}{l}\text { Neonatal disease, } 8 \mathrm{~d} \text {, OTCase } \\
\text { activity }=0\end{array}$ \\
\hline 5 & 174 & $\mathrm{GCT} \rightarrow \mathrm{CCT}$ & $\mathrm{Ala} \rightarrow$ Pro & $\begin{array}{l}\text { Interdomiain } \\
\mathrm{H} 5\end{array}$ & $\mathrm{H} 12$ & $\begin{array}{l}\text { Prolines destabilise helices. This residue is } \\
\text { at contact point between helix } 5 \text { and } 9 \\
\text { which affects orientation of the two } \\
\text { domains, weakens interdomain interface }\end{array}$ & Female, 3 y, peak NH3 300 \\
\hline 5 & 180 & $\mathrm{CAG} \rightarrow \mathrm{CAC}$ & $\begin{array}{l}\text { Gln } \rightarrow \text { His }+ \\
\text { donor splice } \\
\text { error? }\end{array}$ & $\begin{array}{l}\text { Interdomain } \\
\text { H5 }\end{array}$ & $\mathrm{H} 1$ & $\begin{array}{l}\text { Relative orientation between helix } 1 \text { and } 5 \\
\text { important for domain geometry } \\
\text { Possibly inefficient translation of correct } \\
\text { message owing to splice error }\end{array}$ & $\begin{array}{l}\text { Neonatal disease, } 5 \mathrm{~d} \text {, peak } \mathrm{NH} 3 \\
>380\end{array}$ \\
\hline 6 & 182 & $\mathrm{CAC} \rightarrow \mathrm{CTC}$ & His $\rightarrow$ Leu & Equatorial $\mathrm{H} 5$ & $\mathrm{H} 12, \mathrm{~S} 10$ & $\begin{array}{l}\text { Decreases stability of Orn domain by loss of } \\
\text { ionic interaction with D297 }\end{array}$ & Neonatal disease, $<72 \mathrm{~h}$ \\
\hline 6 & 183 & $\mathrm{TAT} \rightarrow \mathrm{TGT}$ & Tyr $\rightarrow$ Cys & Equatorial $\mathrm{H} 5$ & S6, S9, S10 & Decreases stability of Orn domain & $\begin{array}{l}\text { Neonatal disease, }<72 \mathrm{~h} \text {, OTCase } \\
\text { activity }=0\end{array}$ \\
\hline 6 & 192 & $\mathrm{AGC} \rightarrow \mathrm{AGG}$ & Ser $\rightarrow$ Arg & Equatorial S6 & S7, S9 & $\begin{array}{l}\text { Part of beta sheet which forms core of } \\
\text { equatorial domain. Changes disrupt } \\
\text { structure }\end{array}$ & $\begin{array}{l}\text { Neonatal disease, } 2 \mathrm{~d} \text {, peak } \\
\mathrm{NH} 3=1212 \text {, OTCase activity }=0\end{array}$ \\
\hline 6 & $195 \|$ & $\mathrm{GGG} \rightarrow \mathrm{AGG}$ & Gly $\rightarrow$ Arg & Equatorial S6 & S7, S9, S10 & $\begin{array}{l}\text { Part of beta sheet which forms core of } \\
\text { equatorial domain. Changes disrupt local } \\
\text { structure }\end{array}$ & Female, infancy \\
\hline 6 & $196 \|$ & $\mathrm{GAT} \rightarrow \mathrm{GTT}$ & Asp $\rightarrow$ Val & Equatorial & S9 & $\begin{array}{l}\text { Part of beta sheet which forms core of } \\
\text { equatorial domain. Changes disrupt local } \\
\text { structure }\end{array}$ & $\begin{array}{l}\text { Neonatal disease, } 5 \mathrm{~d} \text {, peak } \\
\text { NH3 }=497 \\
\text { OTCase activity }=7 \% \text {, Orn } \mathrm{Km}- \\
20 \mathrm{mmol} / 1 \\
\text { CP Km-normal }\end{array}$ \\
\hline 6 & 203 & $\mathrm{TCC} \rightarrow \mathrm{TGC}$ & Ser $\rightarrow$ Cys & Equatorial $\mathrm{H} 6$ & H5 & $\begin{array}{l}\text { Interacts with active site residue } \mathrm{H} 168 \text {, as } \\
\text { well as interactions which orient the two } \\
\text { domains }\end{array}$ & $\begin{array}{l}\text { Female, } 2 \mathrm{y} \\
\text { brother died at } 6 \mathrm{~d} \text { (neonatal } \\
\text { disease) }\end{array}$ \\
\hline 6 & 216 & $\mathrm{CAG} \rightarrow \mathrm{GAG}$ & Gln $\rightarrow$ Glu & Equatorial S7 & S6, S8 & $\begin{array}{l}\text { Part of beta sheet which forms core of } \\
\text { equatorial domain. Changes disrupt } \\
\text { structure }\end{array}$ & Neonatal disease \\
\hline 7 & 225 & $\mathrm{CCG} \rightarrow \mathrm{CTG}$ & Pro $\rightarrow$ Leu & $\begin{array}{l}\text { Equatorial } \\
\text { before } \mathrm{H} 7\end{array}$ & S7, S8 & $\begin{array}{l}\text { Folding of equatorial domain affected by } \\
\text { changes to the helix start position }\end{array}$ & $\begin{array}{l}\text { Neonatal disease, }<72 \mathrm{~h} \text {, peak } \\
\text { NH3 } \sim 2000, \text { OTCase activity }=0\end{array}$ \\
\hline 7 & 225 & $\mathrm{CCG} \rightarrow \mathrm{ACG}$ & Pro $\rightarrow$ Thr & $\begin{array}{l}\text { Equatorial } \\
\text { before } \mathrm{H} 7\end{array}$ & S7, S8 & $\begin{array}{l}\text { Folding of equatorial domain affected by } \\
\text { changes to the helix start position }\end{array}$ & Late onset, $8 \mathrm{y}$, peak NH3 $=379$ \\
\hline 8 & 247 & ACA $\rightarrow$ AAA & Thr $\rightarrow$ Lys & $\begin{array}{l}\text { Equatorial } \\
\text { S8 }\end{array}$ & S7 & & $\begin{array}{l}\text { Neonatal disease, }<72 \mathrm{~h} \text {, peak } \\
\text { NH3 } \sim 2000, \text { OTCase activity }=0\end{array}$ \\
\hline 8 & 264 & $\mathrm{ACT} \rightarrow \mathrm{GCT}$ & Thr $\rightarrow$ Ala & $\begin{array}{l}\text { Equatorial } \\
\mathrm{S} 9\end{array}$ & S6 & $\begin{array}{l}\text { Part of beta sheet which forms core of } \\
\text { equatorial domain. Changes disrupt } \\
\text { structure }\end{array}$ & $\begin{array}{l}\text { Late onset, } 4 \text { y, peak NH3 }=175 \text {, } \\
\text { OTCase activity }=22 \%\end{array}$ \\
\hline 8 & $268 \|$ & ATG $\rightarrow$ ACG & Met $\rightarrow$ Thr & $\begin{array}{l}\text { Equatorial } \\
\text { end S9 }\end{array}$ & & $\begin{array}{l}\text { Postulated Orn binding residues: } 267-269 \\
\text { are all conserved, correspond to ATCase } \\
\text { residues binding aspartate alpha carboxyl }\end{array}$ & $\begin{array}{l}\text { Late onset, } 6 \text { mth, peak } \mathrm{NH}_{3}= \\
164 . \text { OTCase activity }=6 \cdot 7 \%\end{array}$ \\
\hline 8 & 277 & $\mathrm{CGG} \rightarrow \mathrm{TGG}$ & Arg $\rightarrow$ Trp & $\begin{array}{l}\text { Equatorial } \\
270 \text { 's loop }\end{array}$ & & Affects conformation of Orn active site & $\begin{array}{l}\text { Late onset, } 13 \text { mth, peak } \mathrm{NH} 3= \\
406, \text { OTCase activity }=2-4 \% \text { at } \\
\mathrm{pH} 7.5,19 \% \text { at } \mathrm{pH} 8 \cdot 5, \mathrm{Orn} \\
\mathrm{Km}=8.3 \mathrm{mmol} / 1 \text { at } \mathrm{pH} 7.5 \mathrm{CP} \\
\mathrm{Km} \text {-normal }\end{array}$ \\
\hline 8 & 277 & $\mathrm{CGG} \rightarrow \mathrm{CAG}$ & Arg $\rightarrow \mathrm{Gln}$ & $\begin{array}{l}\text { Equatorial } \\
\text { H9 }\end{array}$ & & Affects conformation of Orn active site & $\begin{array}{l}\text { Late onset, } 8 \mathrm{mth} \text {, peak } \mathrm{NH} 3= \\
150 \text {, normal NH3 and plasma Gln } \\
\text { off therapy, OTCase activity = } \\
50-60 \% \text {, Orn Km }=2-3 \mathrm{mmol} / 1 \\
\text { CP Km-normal } \\
\text { (continued) }\end{array}$ \\
\hline
\end{tabular}




\begin{tabular}{|c|c|c|c|c|c|c|c|}
\hline Exon & Codon* & Mutation & $\begin{array}{l}\text { Amino acid } \\
\text { change }\end{array}$ & Location $†$ & $\begin{array}{l}2^{\circ} \text { structure } \\
\text { interactions }\end{array}$ & Postulated structure/function effect $\ddagger$ & Clinical/biochemical phenotype $\$$ \\
\hline 9 & $304 \|$ & TTG $\rightarrow$ TTT & Leu $\rightarrow$ Phe & Equatorial & $\mathrm{H} 12$ & $\begin{array}{l}\text { Part of Orn binding site } \\
\text { Interactions with other Orn active site } \\
\text { residues and interdomain interactions with } \\
\text { R92 in CP binding site affect activity }\end{array}$ & $\begin{array}{l}\text { Late onset, } 7 \text { mth, peak } \\
\text { NH3 } \sim 400, \text { OTCase activity }= \\
3 \cdot 7 \%\end{array}$ \\
\hline 9 & 309 & $\triangle \mathrm{GAA}$ & $\begin{array}{l}\text { Deletion of } \\
\text { Glu }\end{array}$ & $\begin{array}{l}\text { Equatorial } \\
\text { H11 }\end{array}$ & & $\begin{array}{l}\text { Structural changes affect the } 100 \% \\
\text { conserved residues important for Orn } \\
\text { binding along residues } 301-305\end{array}$ & $\begin{array}{l}\text { Late onset disease, } 2 \mathrm{y} \text {, peak } \\
\text { NH3 } 200 \\
\text { OTCase activity }=2 \cdot 4 \%\end{array}$ \\
\hline $\begin{array}{l}9 \\
10\end{array}$ & $\begin{array}{l}320 \\
343\end{array}$ & $\begin{array}{l}\text { CGA } \rightarrow \text { CTA } \\
\text { ACA } \rightarrow \text { AAA }\end{array}$ & $\begin{array}{l}\text { Arg } \rightarrow \text { Leu } \\
\text { Thr } \rightarrow \text { Lys }\end{array}$ & $\begin{array}{l}\text { Equatorial } \\
\text { Polar }\end{array}$ & S9 & $\begin{array}{l}\text { Affects folding of equatorial domain } \\
\text { Buried charges are unfavourable }\end{array}$ & $\begin{array}{l}\text { Neonatal disease } \\
\text { Female, } 8 \text { y, peak NH3 }=250\end{array}$ \\
\hline & & & & & & $\begin{array}{l}\text { Destabilises helix } 9 \text {, affecting orientation of } \\
\text { equatorial domain }\end{array}$ & \\
\hline 10 & 345 & $\mathrm{TAC} \rightarrow \mathrm{GAC}$ & $\mathrm{Tyr} \rightarrow$ Asp & Polar & & & $\begin{array}{l}\text { Female, } 33 \text { mth, peak NH3 }=525, \\
\text { OTCase activity }=3-16 \%\end{array}$ \\
\hline
\end{tabular}

* Codon number from the translation start site.

$\dagger$ Location of the amino acid change within the OTCase structure and functional domain.

$\$$ The predicted alteration of structure/function as a result of the amino acid change.

Clinical and biochemical data reported on patients affected by the respective mutations.

The data include age of onset of clinical symptoms of hyperammonaemia, highest ammonia level documented in $\mu$ mol/1, residual liver OTCase enzymatic activity in percent of normal, and other biochemical studies on the liver enzyme.

When the mutation is known only in a heterozygous female, it is so noted.

$100 \%$ evolutionary conserved in an alignment of 26 OTCases from various species.

$\mathrm{CP}=$ carbamyl phosphate, Orn = ornithine, spf - sparse fur, spfASH - sparse fur abnormal hair and skin.

group in L-asparate is the $\alpha$ amino group, some differences in the binding sites of the amino acid substrates of the two enzymes are expected. Thus, Lys 84, Arg 167, Arg 229, Glu 231, and Pro 266 (ATCase sequence) in the binding site for L-aspartate of ATCase have different counterparts in OTCase. In ATCase, Arg 167 interacts with the $\alpha$ carboxylate of Laspartate, Arg 229 and Gln 231 interact with its $\beta$ carboxylate, and Lys 84 interacts with both. ${ }^{32}$ In OTCase, Val 120 , possessing a nonpolar side chain, replaces the positively charged side chain of ATCase Lys 84 and hence cannot interact with charged groups of the substrate. However, Glu 122 nearby is strongly conserved and probably interacts with the $\alpha$ amino group of ornithine. In addition, Met 268 and Arg 270 of OTCase which replace Arg 229 and Glu 231 of ATCase may interact with the methylene groups of the ornithine side chain.

Kuo et $a l^{12}$ have shown that $\mathrm{Zn}$ (II) induces cooperativity and a conformational change in $E$ coli OTCase by binding to a Cys residue at the ornithine binding site. Human OTCase also has a Cys residue at the putative ornithine binding site (Cys 303) with four His residues (His 168,202 , and 302 of one subunit and His 117 in the adjacent subunit) $2-10 \AA$ away. Some or all of these residues could act as ligands for a bound metal ion if they were brought closer together by a small conformational change. Therefore, it is possible that binding of $\mathrm{Zn}$ (II) or another divalent metal ion at this site may also induce a conformational change and cooperativity in human OTCase.

\section{EVOLUTIONARY CONSERVED RESIDUES}

The pattern of conserved residues in OTCase which identifies groups that are likely to be important in folding, catalysis, or stability is illustrated in fig 2 . Of the 39 highly conserved OTCase residues, 25 are also present in the alignment with ATCase used to generate this OTCase model, either in its carbamyl phosphate binding site (fig $3 \mathrm{~A}$ ) or in the cores of its domains. Thirty-eight out of the 40 amino acid alterations in OTCase that are inferred from the mutations listed in the table are not present in any of the 26 OTC genes which have been sequenced. This observation strongly suggests that the 38 mutations have deleterious effects on folding, stability, or catalysis. However, two mutations associated with neonatal presentations, $\mathrm{I} 172 \mathrm{M}$ and $\mathrm{Q} 180 \mathrm{H}$, occur normally in other species. The possible mechanisms for the deleterious effect of both mutations are discussed below.

Conserved residues were mapped on the three dimensional model, as illustrated in fig 3A. Residues that are conserved in all known OTCases are concentrated in three clusters: the interdomain crevice, the tip of the polar domain (both of which together form the active site), and the cores of these domains. Residues in the first two clusters are involved in catalysis while those in the third are required to maintain the structural integrity of the protein. Among the OTCases, there is somewhat greater sequence conservation in the polar domain, which binds carbamyl phosphate, than in the equatorial domain, which binds L-ornithine.

\section{LOCALISATION AND EFFECTS OF AMINO ACID}

ALTERATION ON HUMAN OTCASE

Of approximately 70 mutations and polymorphisms affecting the human OTC gene, 40 mutations (38 missense alterations and two in frame deletions) have been identified in the sequence encoding the mature enzyme. These have been classified in terms of the age of onset and severity of OTCase deficiency. The table summarises all 40 mutations and the resulting amino acid changes, their location on the OTCase model, the expected structure/function effects, and relevant clinical information of the respective patients. The mutations described in the table are mapped on the OTCase model as illustrated in fig $3 C$ and $D$. The majority of mutations were found in patients with acute neonatal hyperammonaemia and are expected to be more severe. They affect three regions: at or near the active site, at the interface between subunits, or in the cores of the domains. As expected, this is the same pattern as 
seen with residues conserved between species. The postulated structural basis of a few of these mutations is discussed below in more detail to illustrate the utility of the model.

Of the mutations causing neonatal disease, R141Q recurs among mutations examined to date. Arg 141 forms contacts with His 168 at the carbamyl phosphate binding site. The neonatal OTCD that results when Arg 141 is replaced by Gln can be attributed to the disruption of this interaction. A different mechanism for loss of function is probably responsible for the deleterious effect of the D126G mutation causing neonatal OTCD. Here, the elimination of a salt bridge to Arg 306 of the putative ornithine binding site in the adjacent polypeptide would probably result in disruption of the tertiary and quaternary structure of the active site.

In contrast, several mutations that result in milder, late onset OTCD are often found in regions of the structure that would not be expected to be directly involved in function. Some of these mutations occur in regions that are conformationally flexible in ATCase. For example, Arg 277, the site of another recurrent mutation involving a $\mathrm{CpG}$ dinucleotide $(\mathrm{R} 277 \mathrm{~W} / \mathrm{Q})$ is part of a flexible protein loop that in ATCase swings in towards the active site when L-aspartate binds to the enzyme. Mutations at this site in OTCase may alter the conformation of this loop and propagate their effects to the equatorial domain by subtle conformational changes. Lys 88 located near the carbamyl phosphate binding site provides a second example. Its side chain is not positioned in the model in a way that would allow it to interact with carbamyl phosphate. Instead, it appears to form a salt bridge with Glu 273, and a hydrogen bond with Asn 199, in the ornithine binding domain. In ATCase, the corresponding residues are involved in closing the crevice between the two domains when L-Asp binds. ${ }^{33}$ The charges in the OTCase salt bridge are reversed from those in ATCase, a structural modification that is probably required to accommodate the change in function. The negatively charged Glu 273 is near the ornithine binding site, while in ATCase the corresponding residue near the aspartate binding site is an Arg.

Mutations that would be compensatory if they coexist sometimes occur in neighbouring residues. For example, S192R or Q216E would each alone result in severe OTCase dysfunction since both are part of the core of the equatorial domain. In combination, however, as rare as it would be, their deleterious effects would be attenuated by the formation of a new salt bridge that would neutralise the opposite charges introduced by the mutations. Thus when assessing the deleterious effect of mutations, compensatory changes need to be sought and ruled out. A related example is provided by the I172M mutation near the active site. This is one of the mutations associated with neonatal disease that is found normally in OTCases from other species. This mutation results in a hydrophobic side chain being replaced by a similar residue with somewhat different pack- ing characteristics. In those OTCases in which this substitution occurs, Ser 207 is replaced by either Leu or Ile, presumably to maintain favourable packing interactions. Since this does not happen when the I172M mutation occurs in human OTCase, neonatal OTCD is likely to occur.

The deleterious effects of some mutations may result from their effects on transcription or translation, rather than altering the three dimensional structure of the mature protein. This is probably the case with $\mathrm{Q} 180 \mathrm{H}$, a second neonatal mutation found normally in another species, suggesting that by itself it does not give rise to a loss in enzymatic activity or protein stability. A His residue is found at this position in the anabolic OTCase of Pseudomonas aeruginosa. The effects of this mutation may result from a splicing error, since this mutation changes the terminal nucleotide of exon 5 from $G$ to $C$ and all the exons of normal human OTCase have $G$ as their last nucleotide ( $G$ is present in $78 \%$ of mammalian splice junctions while $\mathrm{C}$ is present in $3 \%{ }^{34}$ ). Moreover, this splice junction may be less efficient already owing to a relatively uncommon intronic sequence of GTTGG relative to the consensus sequence of GT(A or G)AG. ${ }^{34}$ Thus, any additional unfavourable replacement may have a deleterious effect on correct splicing at this site.

The table summarises the predicted effects of many other mutations on the structure and function of OTCase based on the structural model described here. It is impossible to discuss them all in this publication; however, we hope that the information that was included will help investigators to determine whether a particular mutation found in the OTC gene is likely to be deleterious or an innocent polymorphism.

This work was supported by NIH Grant DK17735 (NA) and The Minnesota Medical Foundation.

1 Brusilow SW, Horwich AL. Urea cycle enzymes. In: Scrive $\mathrm{R}$, Beaudet AL, Sly WS, Valle D, eds. The molecular and metabolic bases of inherited disease. New York: McGrawmetabolic bases of inherice

2 Lindgren V, Martinville B, Horwich AL, Rosenberg LE, Francke U. Human ornithine transcarbamylase locus mapped to band Xp21.1 near the Duchenne muscular dystrophy locus. Science 1984;226:698-700.

3 Horwich AL, Fenton WA, Williams KR, et al. Structure and expression of a complementary DNA for the nuclear coded precursor of human mitochondrial ornithine transcarbamylase. Science 1984;224:1068-74.

4 Hata A, Tsuzuki T, Shimada K, Takiguchi $M$, Mori $M$, Matsuda I. Structure of the human ornithine transcarbamylase gene. $₹$ Biochem 1988;103:302-8.

5 Kalousek F, Francois B, Rosenberg LE. Isolation and characterization of ornithine transcarbamylase from normal human liver. $\mathcal{F}$ Biol Chem 1978;253:3939-44.

6 Tuchman M. Mutations and polymorphisms in the human ornithine transcarbamylase gene. Hum Mutat 1993;2:174 8.

7 Tuchman M, Plante RJ. Mutations and polymorphisms in the human ornithine transcarbamylase gene: mutation update addendum. Hum Mutat 1995;5:293-5.

8 Cathelineau L, Briand P, Petit F, Nuyts JP, Farriaux JP, Kamoun PP. Kinetic analysis of a new human ornithine carbamoyltransferase variant. Biochim Biophys Acta 1980; 614:40-5.

9 Gerhart JC, Schachman HK. Allosteric interactions in aspartate transcarbamylase. II. Evidence for different conformational states of the protein in the presence and absence of specific ligands. Biochemistry 1968;7:538-52.

10 Honzatko RB, Crawford JL, Monaco HL, et al. Crystal and molecular structures of native and CTP ligated astal and carbamoyltransferase from Escherichia coli. $7 \mathrm{Mol} B$ iol 1982;160:219-63.

11 Legrain C, Stalon V. Ornithine carbamoyltransferase from Escherichia coli W purification, structure and steady-state kinetic analysis. Eur 7 Biochem 1976;63:289-301.

12 Kuo LC, Lipscomb WN, Kantrowitz ER. Zn(II)-induced 
cooperativity of Escherichia coli ornithine transcarbamylase. Proc Natl Acad Sci USA 1982;79:2250-4.

13 Lee $S$, Shen WH, Miller AW, Kuo LC $\mathrm{Zn}^{2+}$ regulation of ornithine transcarbamoylase. F Mol Biol 1990;211:255-69.

14 Kuo LC, Caron C, Lee S, Herzberg W. $\mathrm{Zn}^{2+}$ regulation of ornithine transcarbamoylase II. Metal binding site. $\mathcal{f} \mathrm{Mol}$ Biol 1990;211:271-80.

15 Miller AW, Kuo LC. Ligand-induced isomerizations of Escherichia coli ornithine transcarbamylase. F Biol Chem 1990;265:15023-7.

16 Houghton JE, O'Donovan GA, Wild JR. Reconstruction of an enzyme by domain substitution effectively switches substrate specificity. Nature 1989;338:172-4.

17 Kuo LC, Seaton BA. X-ray diffraction analysis on single crystals of recombinant Escherichia coli ornithine transcarbamoylase. 7 Biol Chem 1989;264:16246-8.

18 Allewell NM. Escherichia coli aspartate transcarbamylase: structure, energetics and catalytic and regulatory mechstructure, energetics and catalytic and regulatory
anisms. Annu Rev Biophys Chem 1989;18:71-92.

19 Wild JR, Wales ME. Molecular evolution and genetic engineering of protein domains involving aspartate trans-

20 Houghton JE, Bencini DA, O'Donovan GA, Wild JR. Protein differentiation: a comparison of aspartate transcarbamoylase and ornithine transcarbamoylase from Escherichia col K-12. Proc Natl Acad Sci USA 1984;81:4864-8.

21 Altschul SF, Gish W, Miller W, Myers EW, Lipman DJ. Basic local alignment search tool. F Mol Biol 1990;215 403-10.

22 Genetics Computer Group. Program manual for the GCG package version 7 . Madison, WI: 1991.

23 Needleman SB, Wunsch CD. A general method applicable to the search for similarity in the amino acid sequence of 2 proteins. F Mol Biol 1970;48:443-53.
24 Jones TA. A graphics model building and refinement system for macromolecules. I Appl Cryst 1978;11:268-72.

25 Kosman RP, Gouaux JE, Lipscomb WN. Crystal structure of CTP-ligated T state aspartate transcarbamoylase at $2 \cdot 5$ Angstroms resolution: implications for atcase mutants and the mechanis

26 Powell MJD. Restart procedures for the conjugate gradient method. Mathematical Programming 1977;12:241-54.

27 Brünger AT. X-PLOR manual, version 3.1. A system for $x$ ray crystallography and NMR. New Haven: Yale University Press, 1992:382.

28 Rost B, Sander C. Prediction of protein structure at better than 70\% accuracy. $7 \mathrm{Mol}$ Biol 1993;232:584-99.

29 Rost B, Sander C, Schneider R. PHD - an automatic mail server for protein secondary structure prediction. Comput Appl Biosci 1994;10:53-60.

30 Rost B, Sander C. Combining evolutionary information and neural networks to predict protein secondary structure. neural networks to predi

31 Rossman MG, McElvaney KD, Borders CL. Chemical and biological evolution of a nucleotide-binding protein. Nature 1974;250:194-9.

32 Lipscomb WN. Activity and regulation in aspartate transcarbamylase. In: Proceedings of the Robert $A$ Welch Foundation conference on chemical research $X X X V 1$. Houston: Robert A Welch Foundation, 1992:103-43.

33 Newton CJ, Kantrowitz ER. Importance of domain closure for homotropic cooperativity in Escherichia coli aspartate transcarbamylase. Biochemistry 1990;29:1444-51.

34 Shapiro MB, Senapathy P. RNA splice junctions of different classes of eukaryotes: sequence statistics and functional implications in gene expression. Nucleic Acids Res 1987; 15:7155-75. 